\title{
On Why Psychotherapy Must Be a Secular Discipline
}

\author{
Seán Manning
}

PSYCHOTHERAPIST, DUNEDIN

\begin{abstract}
I argue in this article that religion is dangerous, providing some historical and current examples. I explore the phenomenon of religious and spiritual belief from a scientific perspective, particularly using the ideas of psychologist and neuroscientist Michael Graziano who suggested that our social perceptual system is responsible not only for constructing models of other minds, but also for creating Gods and spirits in our own image, and for creating models of our own minds. These observations lead to the central argument that psychotherapy, in studying mind and attempting to ameliorate its discomforts, must treat the perception of a spirit world in the same way that it treats our perception of our own and others' minds and selves, and therefore must maintain a religiously secular stance.
\end{abstract}

\section{Waitara}

I roto i tēnei tuhing e whakapae ana au he mōrearea te hāhi, ā, ka whakarato i ètahi tauira o mua o nāianei hoki. Ka hōrapahia pēnei ki tā te mātauranga pūtaiao te āhua o te hāhi me te whakapono wairua, aro kau nei ki ngā whakaaro o te kaimātai hinegaro me te kaimātai pūtaiaoio a Mikaere Karatiano e kī nei ko te ture aronga a tō tātau hāpori te take mō te mahi tauira o ètahi atu hinengaro, me te hanga Atua, wairua pēnei ki ō tātau ake hanga, à, hei hanga ata o ō tātau ake hinegaro. Nā ēnei tirohanga ka tākina ki te pūtake o te tautohe i te wā wānangahia e te kaiwhakaora hinengaro te hinengaro ka whakatete ki te whakakora i aua mānukanuka me āta huri ki te whakaora i te tirohanga ki te ao wairua pēnei anō i te whāwhā i tā tātau tirohanga ki ō tātau ake me ō ètahi atu hinengaro, whaiaro hoki,ā, me mātua mau ki tētahi tirohanga hāhi noa.

Keywords: religion; spirituality; perception; secularism

People being who we are, masters of inconsistency, we are able to be irrational and at the same time intellectually aware of it. (Graziano, 2010, p.164)

Manning, S. (2015). On why psychotherapy must be a secular discipline. Ata: Journal of Psychotherapy Aotearoa New Zealand, 19(2),159-172. DOI:10.9791/ajpanz.2015.15 ( ) New Zealand Association of Psychotherapists Inc. 


\section{Religion and Violence}

Elijah walked about the northern kingdom of Israel, where since 869 BCE the ruler had been Ahab, preaching the doctrine of Yahweh, reminding the people of the covenant authored by Joshua, in which their ancestors had promised to forsake all Gods but Him. No one doubted that other Gods existed - Yahweh had never claimed that, and would not, until after the exile in Babylon - the Covenant only insisted that the Israelites would not worship them (Armstrong, 1993/1999). This was a problem, because while Yahweh had proved himself as a war God, he had no track record in fertility, and when the nation of Israel settled in Caanan, they knew very well that it had been Baal who made the crops grow as long as anyone could remember. Moreover, Solomon had designed his temple along the lines of pagan temples and had been famously inclusive, having many pagan wives and permitting people to worship whomever they wanted, even within the bounds of the temple. Then there was Ahab's wife, Jezebel, who, unusually, proselytised on behalf of paganism, had some followers of Yahweh put to death, and imported 600 priests of Baal. It was unusual because pagans did not need to convert; in their temples you could worship many gods, and one more or less, including Yahweh, made no difference. (There is of course another side to this story - Jezebel was a Phoenician princess who was married off to an Israeli prince to cement a political alliance. She came from a vibrant, colourful, multi-cultural trading society with many Gods to an ultra-conservative mono-cultural, monotheistic agrarian one and might be forgiven for trying to introduce some diversity.)

A competition was arranged. Two altars, each with a bull, were set up. All morning the priests of Baal prayed for fire from heaven to consume the sacrifice. Elijah mocked them. Perhaps Baal is busy, after all, he is a God with much to attend to, or perhaps he is asleep, pray louder, you may wake him. There was no fire. Then Elijah raised his voice to heaven and immediately fire descended and consumed both the altar and the bull. People were impressed, as we can imagine, but Elijah did not stop there. He instructed the people to lay hands on the priests of Baal, take them to the shores of the river, and there Elijah killed them. It is not recorded whether he massacred all 6oo, but he would not have hesitated. He killed them because they prayed to the wrong God.

In perpetrating this atrocity, Elijah was building on a tradition attributed to Moses himself:

And when the Lord thy God hath delivered it into thine hands, thou shalt smite every male thereof with the edge of the sword:...

.. thou shalt save alive nothing that breatheth:

... thou shalt utterly destroy them; namely, the Hittites, and the Amorites, the Canaanites, and the Perizzites, the Hivites, and the Jebusites; as the Lord thy God hath commanded thee:

That they teach you not to do after all their abominations, which they have done unto their gods; so should ye sin against the Lord your God. (Deuteronomy 20,13-18, King James Version)

Now therefore kill every male among the little ones, and kill every woman that hath known man by lying with him. 
But all the women children, that have not known a man by lying with him, keep alive for yourselves. (Numbers 31,17-18)

And he that blasphemeth the name of the Lord, he shall surely be put to death, and all the congregation shall certainly stone him: as well the stranger, as he that is born in the land, when he blasphemeth the name of the Lord, shall be put to death. (Leviticus 24,16)

For the sake of accuracy it is worth mentioning that there is some evidence that parts of this description of God's instructions for how the Israelites were to invade Caanan were added 200 years later. There is reasonable conjecture that Deuteronomy is actually the Book of Laws, discovered, or possibly written by, the High Priest Hilkiah in the mid-6oos BCE, and that some older books were altered at this time to reflect a more assertive and warlike history (Armstrong, 1999).

These old books, the foundation first of Judaism, then Christianity, and later of Islam, are replete with detailed instructions for mass murder and rape. Today, there are fundamentalist Christians who would put people to death for adultery (Dawkins, 2006), there are Muslims who will kill anyone who has the wrong God (Knecht, 2015), and there are ISIS fighters who pray to Allah before raping a slave girl (Rasheed, 2014). Within living memory, in 1982 in Beirut, some 3,000 Shiite women, old men, and children were killed by the Christian Phalange and in 1995, Christian militias massacred 8,000 men and boys at Srebrenica. From Elijah to ISIS, these great religions have always countenanced violence and still do.

True, Christianity has the mitigating influence of the New Testament, a message of love and tolerance from a prophet who liked to go to the pub, but the traditional violence of monotheism was actually scarcely modified at all. The iconography of Christianity is unremittingly violent. The beautiful churches of Europe are populated with violent images; angels and saints, wrought in precious metal or carefully painted, with swords and spears are to be found killing devils and sinners and threatening the congregation. Images of hell depicting endless torture are common and, of course, the central icon, the symbol at the very heart of Christianity, is a scene of utmost agony and humiliation.

From the Inquisition, through the crusades, through countless "witch" burnings, to Srebrinica and Sabra, Christianity has maintained the old ways alongside the new.

Currently Islam is perhaps more of a threat but this may simply be, as neuroscientist and philosopher Sam Harris pointed out, because Islam has more believers (Harris, 2005). In predominantly Muslim countries, those who believe that suicide bombing is sometimes justified vary between a low of $20 \%$ in Turkey to a high of $82 \%$ in Lebanon. And Islam may have more believers simply because of poverty and poor educational standards.

Another theory about the influence of fundamentalism is that it arises where identity and security is threatened, as happened in the 6th and 7 th centuries BCE when the ancient kingdoms of Judah and Israel were internally divided and fell prey first to Syria and then Babylon. Karen Armstrong, a scholar of religion and a former nun, suggested in her powerful History of God (1993/1999), that this explains why Christian fundamentalism and particularly the belief in being specially chosen by God is so evident in the United States today.

When I presented these histories recently a member of the audience, whose views I have 
reason to respect, commented that it is not religion that kills people, it is people who kill people. There is justice and reason in this argument, and I would like to accept it. My early memories of the ceremonies in a stone Church of Ireland church and its benign minister support this point of view. However, for reasons which I will discuss below, I am aware that it is not a good idea to take my experience as "evidence" over objective science. The argument that "it is people who kill people" seems rather similar to saying that guns do not kill people. One can find posters associated with the US National Rifle Association, an organisation that thinks crime can be stopped by putting a gun in the hands of every citizen, saying that if guns kill people, then ropes commit suicide, pencils misspell words and forks make people fat. The argument is false - fewer guns means fewer casualties. Less religion means less violence.

Another idea that does not hold up is the argument that religious violence is the work of fanatics. There are simply too many of them. Hypotheses which suggest that they are poor, uneducated or manipulated by unscrupulous powers do not work either. Various analyses of suicide bombers, to take one special group, come up with benevolence, selfsacrifice, martyrdom, depression, fear, anger, guilt, narcissism, learning opportunities, cost benefit calculations, and the need to belong as factors that drive the terrorist - too many to be of any use. They are not mostly poor or mostly middle class, they are not mostly graduates of the madrassa nor are they mostly all well- or poorly-educated. In fact, there is no profile of a terrorist, even within the narrow definition of suicide bomber, that has any reliability (Stern, 2003).

My view, based on what I take to be overwhelming evidence, both historical and recent, is that both Christianity and Islam are dangerous, often murderous movements. Notwithstanding the benign Church of Ireland, being brought up in Northern Ireland in a protestant community where some of my childhood friends became members of paramilitary militias and committed, or were implicated in, the murder of Roman Catholics simply because they were Roman Catholics, probably influences my thinking.

\section{What Then of Transformative, Visionary Experience?}

But this is too simple - blanket rejection of religion will not suffice. Transformative experience, transcendence, visions, and "conversion" experiences are so common they must be regarded as a normal part of human awareness. We have between 80 and 100 billion neurones in our brains, each of which is making decisions hundreds of times a second (Graziana, 2010). Each of these has tens of thousands of synapses, making perhaps 1,000 trillion connections (Koch, 2012). Each neural pulse, of about one-tenth of a volt in amplitude, lasts less than one-thousandth of a second. This unimaginably complex system produces a magical event, one which has been, and still is, examined with fascination by philosophers and scientists, from the time when those two disciplines were not distinct from each other to the present, that is to say, consciousness. It would be remarkable if the consciousness produced by this degree of complexity were not at times transformative and visionary. Ordinary wakeful awareness is a miracle in itself, and at times it becomes so fantastic and otherworldly that we feel changed forever by the experience. This is not uncommon.

Many quite ordinary people have quite extraordinary experiences in the midst of 
their everyday lives. These are usually called "religious experiences" if they include visions of angels, spiritual beings, or gods, but mystical experiences if they do not. (Koch, 2012, p. 111)

From out-of-body experiences to fugues and visions, a surprisingly large number of people (perhaps 30-40\%) report quite dramatic spontaneous altered states. (Blackmore, 2012, p. 108)

The Japanese novelist Haruki Murakami described the experience thus:

We have rooms in ourselves. Most of them we have not visited yet. Forgotten rooms. From time to time we can find the passage. We find strange things ... old phonographs, pictures, books ... they belong to us, but it is the first time we have found them. (As cited in Koch, 2012, preface)

This, as Koch puts it, is the entry point for religion.

Religion has an intuitive, plausible explanation for the phenomenon of mind. We are conscious because we have an immaterial soul, our true, inner self. The soul is part and parcel of a transcendental reality, above and beyond the categories of space and time and causality. This soul strives to be united with God at the end of time. $(2012, p \cdot 3)$

Clearly we need an approach to transformative, visionary experience that does not require a spirit world.

\section{Consciousness, Spirit, and Dualism}

Koch's (2012) thesis, and that of his late collaborator, Nobel Prize winner Francis Crick, is that consciousness is a fundamental property of complex things. There are a number of contenders for a theory of consciousness, outstanding among them Guilio Tononi, who, alone among neuroscientists, used a poetic medium to explain his ideas, as well as, in collaboration with Gerald Edelman, a scientific one (Edelman \& Tononi, 2000; Tononi, 2012). Tononi's beautifically and cryptically illustrated book, Phi: A Voyage from the Brain to the Soul, takes us on a journey with Galileo through a series of scenes to explain the brain's magic and its limitations, accompanied by a mysterious modern-day character called Frick, presumably a tribute to Francis Crick. Ultimately, he describes "integrated information", which seems to mean data represented in different ways in different areas, with a kind of feedback loop called "re-entry", when large neuronal groups form a dynamic core in the brain, with connections looping back and forth between the thalamus and cortex, keeping it operative for long enough for it to become experience (see also Blackmore, 2012).

It is not an easy topic. My first encounter with this literature was Antonio Damasio's very readable The Feeling of What Happens (1999), in which emotion is placed at the centre of 
experience, the mover and cause of awareness, itself created by brain machinery that senses the body, in a hierarchy with homeostasis at the base and awareness and thought at the apex. More recently (and somewhat less readable, as it requires of the reader a willingness to engage with neural anatomy) Damasio followed this work with a treatise on how the brain creates the sense of self (2011). These are elegant, evidence-driven theories describing the machinery plausibly and with great scholarship, but arguably still falling short of explaining how matter becomes experience.

Dame Susan Greenfield (2000), using real-time brain imaging studies, suggested a theory of bursts of neural activity, involving several million neurons which seem to represent conscious experience. The idea is not unlike Edelman and Tononi's re-entry (2000), or Tononi's integrated information (2000, 2012).

Michael Graziano (2010) posited a theory of attention, using data on the way the brain chooses which schema - which neural event arising from sensory input, either internal or external - to which it will pay attention. In this model, consciousness arises as a result of attention itself being treated as a schema to which the brain can attend.

All of these models are sophisticated, and are based on good science, which I define as investigation in which researchers demonstrate a willingness to modify theory in the light of new evidence. This is the antithesis of faith, which requires no evidence other than personal experience, and in which the faithful will stand by their beliefs regardless of evidence. So these developments all represent a movement away from the dangers of religious belief.

Yet we must acknowledge that none of these are either simple or satisfying. They all attempt to explain, as Colin McGinn put it (wryly using a religious metaphor) how evolution converted the "water" of biological tissue into the "wine" of consciousness (as cited in Koch, 2012, p. 23). This is what philosopher David Chalmers called, with reason, the "hard problem" (as cited in Koch, 2012, p. 3). How the brain, a collection of squishy soft tissue, creates the experience of being remains just beyond us, despite these promising investigations. One thing they all agree upon, though - this consciousness, however it arises, is all we have.

There have been countless attempts to find evidence for the soul, for the power of prayer, for communication with the dead, astral travel, telepathy, ghosts and spirits, the power of sacred or haunted places, clairvoyance, precognition, all the trappings of spiritual belief. Thousands of experiments have been carried out, often by believers or one-time believers like Susan Blackmore, and, apart from some transparently bad science, none of them have demonstrated anything beyond the working of the human mind (for instance, Blackmore, 1986).

When therapists talk of "spirit" in a manner which suggests Cartesian dualism - as in a phrase like "mind, body and spirit" - implying that these are somehow different substances, or exist on a different plane from each other, an untestable and limiting belief is being suggested. The scientific question, the null hypothesis, will be what if it isn't true, what if there is only what we can see, the body, and what if the experience of mind and spirit are illusions created by the brain?

The 17th century French physicist, mathematician, and philosopher René Descartes, in his "Discourse on the Method of Rightly Conducting the Reason" and "Seeking Truth in the Sciences", sought ultimate certainty. His method was scientific introspection, based on a 
simple proposition - if I can doubt the reality of something, then I should set it aside and look for something that cannot be doubted. Can I doubt that I am here? Yes, so set that aside. Can I doubt that you are here? Yes, set that aside. Can I doubt that I am doubting? No! I most certainly am doubting, otherwise I could not imagine any of this. I doubt, and thus I think, and thus I am. Je pense, donc je suis, or later in Latin, cogito ergo sum.

Descartes was a rationalist who had an enormous impact on European thinking, and was one of a number of influences that weakened the grip of the church on science. However, he was also a Christian, believing in God's act of creation, and he needed to explain how mind arose. He suggested that mind and body consist of different "substances". This is dualism. Consciousness, to Descartes, required an immaterial soul, which he thought resided, or communicated via, the pineal gland, because he observed that it is the only brain structure that is not divided in two.

Dualism, which requires that we observe ourselves from within ourselves, is a discredited idea (for example, see Damasio, 1994; Dennett, 1991). The American philosopher Daniel Dennett described this scenario as the "Cartesian Theatre" in which a homunculus (or a soul) within us observes ourselves and directs our actions. The problem is of course that the homunculus (or soul) itself requires an observer, in an infinite regression. The difficult scientific position, going on available evidence is, as Blackmore put it, that:

The brain is massively parallel and distributed in its design. Information comes in through the senses, and is used to control speech, actions, and other outputs, but there is no central organization; no inner sanctum where the really important bits happen. (2012, p.18)

There is no control centre in the brain. This is annoyingly counterintuitive - I feel as though I am "in here". I can even locate myself as somewhere in my head, typically behind my eyes. When this location is disturbed, as in the relatively common out-of-body experience, I am convinced not only that I normally reside in my head, but that I am separate from it, that I inhabit my body. We can understand how Descartes reached his conclusion. We act every day as though it were true. I am this as well as being that, I am both body and mind, body and soul. Even knowing that this is an illusion, I still feel and act as though it were true.

There is therefore an inescapable difficulty in understanding our experience. All of the evidence from scientific enquiry, everything except my experience of myself, my perception of events, suggests the thesis summarised by Blackmore above (2012); there is no control centre. As far as we can tell, my sense of self is a shifting, made-up narrative which develops and deteriorates as my brain, its source, develops and deteriorates. It is coherent or fragmented as my history dictates, but is essentially temporary, an internal creation, an illusion. Kim Chernin, writing 20 years ago about her experiences in analysis over the previous quarter century, put it well:

The sequence of provisional selves through which we pass in the course of our lives, each lived for its season then sloughed off, leaving behind fossil traces (memory), but no immediate, felt sense of the living being who once occupied one's life.... This sense of fragmentation, this discontinuity, may or may not be a condition peculiar 
to me.(1995, p.10)

Of course this is what makes psychotherapy possible; the narrative must be amenable to change, the self must develop, must improve in coherence, flexibility, and complexity. We must be able to create ourselves. In a practical sense it does not matter that the centre of will is a fiction, as long as it is a useful fiction.

We make up explanations for things, for what we perceive. Sperry's famous experiments on split-brain patients (people whose corpus callosum had been severed to control severe epilepsy, and who now essentially had two independent brains) illustrated how the left hemisphere with its almost exclusive use of language, develops the idea that it is in control, while the right, given a means of expression, has other ideas (for example, see Sperry, 1974). As Graziano put it, “The left hemisphere's delusion that it was in conscious control of the entire body was the most bizarre symptom of the surgery" (2010, p. 63).

This is an example of how the brain accepts a plausible explanation. And religion's strength is that it offers a simple way to grasp experience, the understanding of which, from a scientific standpoint, is much more taxing. Graziano (2010) suggested that the split-brain data revealed the extent to which we rely on confabulation. Our everyday stream-ofconsciousness explanations are not particularly accurate. In this sense, our awareness, our vaunted consciousness, is a perceptual illusion.

\section{The Unreliability of Perception and the Neuroscience of Spirit}

Difficult though this conclusion is, it is again an endorsement of psychotherapy. Starting from the view that the self is an illusion, a constructed narrative, we can be reasonably certain that studying it, reconstructing it, reflecting in the presence of another, in other words the day-to-day business of psychotherapy, is likely to improve its accuracy and usefulness.

Graziano (2012) used Koch's (2012) hypothesis that consciousness, and specifically what we are conscious of, results when a sufficiently strong input arrives at a specific processing unit. The outcome is the result of competition between various possibilities. What marks out Graziano's theory is his suggestion that the key processor that is receiving packets of summed information that result in conscious experience is specifically the circuitry for social intelligence.

Our brains appear to have special-purpose machinery whose job is to attribute volition, intentions, agendas, goals, emotions, and other mental events to other people. This is, of course, an advantage to a social species like ourselves. We need to know the intentions of our own species and it is useful to be able to guess the intentions of other species. The scientific field that studies this is sometimes referred to as "theory of mind". There have been two competing views - that we use imitation and rehearsal to construct a model of another mind, and the mirror neuron theory which developed when in the 1990s a type of nerve cell was discovered in monkeys that responded whether the monkey was performing an action or watching it being performed by someone else, including by a human being (Graziano, 2010).

According to Graziano, our talent for mind reading, or empathy, depends on specialised 
hardware. We have a mechanism for social perception that seems to be co-ordinated in a part of the temporo-pareital junction and the superior temporal polysensory area where we piece together information from various sources to form an impression of another's mind. It is automatic, rapid, and intuitive, more of a feeling about someone else's state of mind than a cleverly contrived theory, and it is quite distinct from our ability to sift information logically or scientifically.

We therefore have two different models for explaining the world. One is helpful in understanding an event - a car that will not start, the structure of my professional association, what attachment schema a client uses. The other attributes intention, a simplified model of another's mind, perceived as a real thing, located inside that person. These mind-models are indistinguishable from spirit. Because it is a simplified, functional model, we tend to see others as having a single intention, a single identity. We know this is not true of ourselves, and we can use our scientific, reflective, cognitive ability to make a more complex appraisal of another, knowing that the brain does not function as a single intentional agent. However, even given considerable training in this ability, we still go for the simple, immediate, functional model.

To illustrate, let me take an ordinary example that we all face from time to time. A client fails to turn up, then fills my call minder with messages that are at first apologetic, then abusive. My first response is to be affronted, how dare she, I have put up with enough of that, what am I, some kind of punching bag? That is the simple, functional model, functional because in a social group I would know to keep away from that person, to be wary. The slower, scientific, system comes into play eventually - hopefully within minutes, though I confess to having taken longer - and I conclude that this is the behaviour of someone whose distress escalates rapidly because there was no soothing other early in life, and who is reaching out to the only person they trust. It is an ambivalent/preoccupied attachment system with disorganisation - like a child who reaches for reassurance but who cannot be calmed.

This process of accessing the thoughtful appraisal system is, of course, the consequence of training and personal therapy. Most of the time we simply believe what we perceive. Soand-so is a good person, so when she is fired for stealing I make excuses for her, she must have been under terrible stress. That one, on the other hand, is a complete bastard, so when he does something nice I am suspicious, I ask what is he up to, what does he want. It takes a lot of evidence to change one's mind once these judgements are in place. What we perceive, we believe.

However, this machinery does not limit itself to perceiving human minds. We populate the world around us with intention. The sea has a temperament, the sky is moody, the hills are foreboding, the mountains purifying, the river has a soul. A small child's cloth monkey has one too. When it is lost, it cannot be replaced with another, because the soul is missing. We perceive soul in plants, in cars, in clothing. It is a short step from here to spirit, ghosts, and God. Because belief is so immediate, so intuitively right, we fail to notice that gods, ghosts, and toy monkeys are actually models of a human mind.

I am suggesting that a belief in God is a natural extension of the way the human brain is wired. What is God but the perception of intentionality on a global scale? ... The difference between the monotheistic Christian god and a ghost who bangs a drawer 
shut is only one of scale. (Graziana, 2010, pp. 47-48)

God is as real to us as the colour red is real. There is no "red" in the universe, there is only electromagnetic radiation with a wavelength of about 650 nanometers that we perceive as red. It is a perception, so we believe it. God is a perception, so we believe.

Angry people, in their religious moments, when their perceptual machinery constructs a model of God's mind, tend to perceive God to be a force of furious punishment, and generous people perceive God to be a source of generosity and love. (Graziano, 2010, p.139)

Thus God has different attributes to different groups, sometimes angry, sometimes loving. The social perceptual brain hardware that intuits intention in everything, that creates gods out of the material world, begins by perceiving emotions, intentions, mind, and soul in ourselves and in others. We use the same mechanism to perceive ghosts and gods, and, according to Graziano (2010), we use the same system to perceive our own minds, our own consciousness, our own soul. We do not know our own mind with clarity. This is not a surprise to psychotherapists. All we know is the model, constructed in the same way we construct a model of the mind of another.

It may seem odd (and it is a difficult idea to get to grips with) to suggest that the mind, consciousness, awareness, is an illusion. It is counterintuitive, contrary to our experience of ourselves, yet there is ample evidence to suggest that this is the case.

\section{A Note on Spiritualty and Religion}

It is not uncommon to differentiate religion from spirituality. Sam Harris (2014), discussing the need to understand transformative experience in the context of neuroscience, noted that such experiences are tied to the worst parts of culture. It seems reasonable, then, when trying to understand experience that is visionary, outside of what we regard as our normal perception of the world, to support the idea of a personal spirituality, a personal experience beyond the scientifically observable, difficult to describe in ordinary language. Barbara Ehrenreich, in her recent autobiography, which is centred on mystical experiences she had as an adolescent, responded harshly.

Here we leave the jurisdiction of language, where nothing is left but the vague gurgles of surrender expressed in words like "ineffable" and "transcendent." For most of the intervening years, my general thought has been: If there are no words for it, then don't say anything about it. Otherwise you risk slopping into "spirituality," which is, in addition to being a crime against reason, of no more interest to other people than your dreams. (Ehrenreich, 2014, p.115)

Harris' (2005, 2014) approach is softer, allowing that we might develop a "secular spirituality". In either case, once we adopt a belief, we leave the realm of science. As Koch put it: “.. my loss of faith is an inescapable part of growing up" (2012, p.166). 
The development of a personal spirituality may be a way out of the confines and dangers of organised religion, but as soon as we declare a belief in something that is not observable, not backed by evidence outside of the unreliable data provided by our senses, we abandon the possibility of understanding the nature of a psyche that often gives rise to remarkable experience. Seen in this way, personal spirituality, while less regimented than religion, springs from the same roots, and is essentially the same phenomenon.

\section{A Note on Indigenous Spirituality}

The spiritual beliefs of indigenous peoples are more likely than the large organised religions to represent humanity as part of a natural world, which itself as a whole or in its parts, has a spiritual dimension. To non-indigenous, colonial peoples, particularly the majority who live in artificial urban environments, who have lost contact with their roots and thus struggle to place themselves in relation to the environment, this is enormously attractive. Indigenous peoples often seem, to westerners, to have a more solid and coherent sense of identity because of this connection to the natural environment. Also, of course, this identity is likely to be fractured when the connection to the land is lost and they are forced to live in cities.

Just as the word "Māori" is used to collectively define the people of Aotearoa New Zealand, yet was never used by those people to describe themselves in pre-colonisation times - it seems to translate as something like "ordinary" - the term "indigenous spirituality" is used to describe something seen from the outside. Perceived in this way by people who are lacking something in their sense of who and what they are, it is easy for colonial peoples to believe that the spiritual beliefs of indigenous peoples are somehow more true than those on offer by the large organised religions.

It seems perfectly reasonable, in a bilingual, bicultural country, to incorporate ritual and protocol into professional contexts such as psychotherapy practice. There is no reason to suppose that imported colonial rituals and protocols - for instance the standing orders for a professional association's AGM, or the manner in which a client is greeted - are superior to those that govern debates and contact among indigenous people - for instance the tîkanga of a particular marae or the custom of hongi. After all, the profession is an expression of all its members, not just the European ones. This is simple respect and partnership, and is governed, in the case of Aotearoa New Zealand, by the principles of a treaty with the British crown, signed in good faith by Māori in 1840 .

This kind of bicultural partnership is not without its difficulties. Where the indigenous people are a minority - and perhaps in other cases where power lies mostly with the colonist - it is reasonable that a degree of protection is offered for their way of doing things, as long as the dialogue is egalitarian and does not slip into patronage. However, one of the consequences of such a partnership is that, while it is rarely dangerous these days for me to rail against the doctrines of the mainstream religions, any attempt to question the beliefs of the indigenous minority runs the risk of being experienced as disrespectful, if not downright racist. For this reason, and because of a simple lack of knowledge, I prefer to confine my arguments to the religion of my own ancestors, and trust that my Māori colleagues are perfectly capable of deconstructing their own belief systems. 


\section{"Belief Is Intellectual Surrender"}

There is of course an extensive literature on the social functions of religion (see, for example, Norenzayan, 2013). A common conclusion is that a shared set of spiritual beliefs provides a sense of collective identity, a focus for social contact, and a set of rules for conduct, allowing a society to work collectively together to develop an economic system. It has been suggested that advanced societies develop their economies and cultures by climbing the ladder of religion, only to kick it away when it is no longer needed. This is certainly a functional hypothesis, and is supported by the observation that economically advanced and egalitarian societies seem to have much less need of religion, and that where the economic system is rudimentary, or where there are inequities, inequalities, poor education, poor health services, and poverty, religion seems to thrive. However, the social theory avoids the problem of why and how we would create such dangerously fantastical beliefs to keep us together. The emerging ideas from neuroscience I have chosen Graziano as a chief source, but there are others - fill this gap for us.

Briefly, the arguments presented above are thus: psychotherapy would do well to avoid adopting spiritual beliefs because religion and spiritual beliefs are dangerous delusions which limit our thinking; spirit, soul, God are constructions of mind, so in order to study mind and to heal its difficulties, we would do well to study spirituality but avoid belief.

Ehrenreich put the scientific position forcefully: "I believe nothing. Belief is intellectual surrender; 'faith' a state of willed self-delusion” (2014, p. 232).

It is entirely possible to have a view of creation that avoids the delusions of religious belief, that is solidly grounded in scientific observation, that is capable of modification in the presence of new evidence, yet gives meaning and depth to experience and provides a rationale for the ethical conduct that seems to arise naturally from our makeup. Should anyone doubt the truth of that last phrase, they are referred to Damasio's Looking for Spinoza (2004) in which a convincing argument is presented that ethics and consensual law arise naturally from human emotion.

Such a view might be phrased thus: when we are gone, when our bodies deteriorate or misfortune destroys them, then we, as individual conscious entities, are finished. We do not continue in some spirit world, we do not join in communion with some divinity, nor are we consigned to a heaven or a hell. We are done, gone forever, our minds, the product of our marvellous physical brains, the subject of our study and the reason for our discipline, are gone just as surely as the brain itself is reduced to compost. The same is true of all living organisms. However, while alive we have been something amazing. We have been a part of the moment when the universe woke up.After 13 billion years, which is how long it took to develop complex carbon-based life forms, first manufacturing that elemental building block in the centre of stars, then flinging it into space as the first generation of stars collapsed, allowing planets with carbon to coalesce and ultimately, here on earth, warmed by a second-generation star, conscious self-awareness emerged. Mind was born, matter became aware of itself, developed the capacity for self-reflection and the ability to control its own destiny, to change the course of evolution. One might imagine a future species looking at our history and saying, there, back then with that human mind, that is where it began, that is where the universe learned to think.

The study of mind therefore has enormous significance and barely imaginable consequences, as long as it is approached from a secular, scientific point of view. But this secularism is not mundane, it is extraordinarily profound. 


\section{SeÁn MANning}

\section{References}

Armstrong, K. (1999). A history of God: The 4000-year quest of Judaism, Christianity, and Islam. London, UK: Random House. (Original work published 1993)

Blackmore, S. J. (1986). The adventures of a parapsychologist. Buffalo, NY: Prometheus Books. Blackmore, S. J. (2012). Consciousness: An introduction. Oxford, UK: Oxford University Press.

Chernin, K. (1995). A different kind of listening. New York, NY: Harper Collins.

Damasio, A. (1994). Descartes' error: Emotion, reason and the human brain. New York, NY: Harper Collins.

Damasio, A. (1999). The feeling of what happens. London, UK: Random House.

Damasio, A. (2004). Looking for Spinoza: Joy, sorrow and the feeling brain. London, UK: Vintage Books.

Damasio, A. (2011). Self comes to mind: Constructing the conscious brain. London, UK: Random House.

Dawkins, R. (Writer and Presenter).(2006). The root of all evil? [Television documentary]. London, UK: Channel 4.

Dennett, D. C. (1991). Consciousness explained. Boston, MA: Little, Brown and Co.

Edelman, G. M. \& Tononi, G. (2000). A universe of consciousness: how matter becomes imagination. New York, NY: Basic Books.

Ehrenreich, B. (2014). Living with a wild god: A non-believer's search for the truth about everything. New York, NY: Twelve.

Graziano, M. S. A. (2010). God soul mind brain: A neuroscientist's reflections on the spirit world. Teaticket, MA: Leapfrog Press.

Greenfield, S. (2000). The private life of the brain: Emotions, consciousness, and the secret of the self. New York, NY: John Wiley \& Sons.

Harris, S. (2005). The end of faith: Religion, terror, and the future of reason. New York, NY: W.W. Norton \& Co.

Harris, S. (2014). Waking up: A guide to spirituality without religion. New York, NY: Simon \& Schuster.

Knecht, E. (2015). Paris attacks: Islamic State claims responsibility for Paris attacks. Retrieved from http://www.stuff.co.nz/world/europe/74039803/Paris-attacks-Islamic-State-claimsresponsibility-for-Paris-attacks

Koch, C. (2012). Consciousness: Confessions of a romantic reductionist. Cambridge, MA: MIT Press.

Norenzayan, A. (2013). Big gods: How religion transformed cooperation and conflict. Princeton, NJ: Princeton University Press.

Rasheed, A. (2014). 500 Yazidis slaughtered by Islamic State. Retrieved from http://www.stuff.co. nz/world/middle-east/10369228/500-Yazidis-slaughtered-by-Islamic-State

Sperry, R. (1974). Lateral specialization in the surgically separated hemispheres. In F. Schmitt and F. Worden (Eds.), Third Neurosciences Study Program pp. 5-19 Cambridge, MA: MIT Press.

Stern, J. (2003). Terror in the name of God: Why religious militants kill. New York, NY: Ecco.

Tononi, G. (2012). Phi: A voyage from the brain to the soul. New York, NY: Pantheon. 


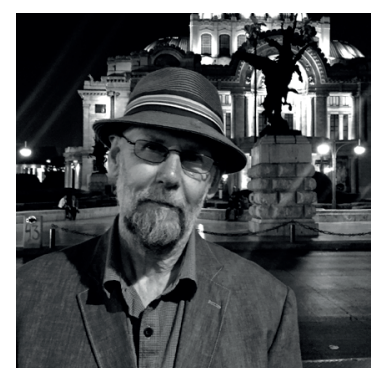

Seán Manning is a psychotherapist attached to a therapeutic community in Dunedin treating male offenders, and with a small private practice. His academic and professional background is in psychology and social work. Raised in Belfast, Northern Ireland, he has lived in Aotearoa New Zealand since 1975. He is 70 years old and has three grown up children and two grandchildren. He has been a former member of the Board of the International Transactional Analysis Association and of the Training \& Certification Council of Transactional Analysts Inc., Chair of Ethics for the Western Pacific Association for Transactional Analysis, and president of the NZ Association of Psychotherapists but recently has developed a social life. His almost adequate command of Māori language is still a lot better than his command of Irish. His addiction to collecting stringed musical instruments is almost under control and his ability to play them is just enough to get him entry into Irish music "sessions".

$\mathrm{He}$ is intensely interested in how psychotherapy works, what happens in the human brain as a result. He has authored a report summarising the effectiveness of psychotherapy and a number of papers on antisocial behaviour and the unconscious. Confessing to being sometimes unreasonable and grumpy, he is passionate about this profession, its place, its meaning and its future in our society. Contact details: seán_manning@xtra.co.nz . 